\title{
Factors Influencing the Construction of Management Information at Colleges and Universities and Analysis of Countermeasures
}

\author{
Min Wei \\ Library, Jilin Agricultural University, Changchun, 130118 \\ 434975141@qq.com
}

Keywords: Colleges, Information Management; Influencing Factors, Countermeasures

\begin{abstract}
With scientific and technological progress and the upcoming era of knowledge economy, education management mechanism against the background of market economy is also constantly changing. Faced with the pressure and challenges from various aspects, traditional management mode at college will be eliminated while the trend of information and science has proposed higher requirement for the construction of management at colleges and universities, the reform of which should be carried out smoothly under the guidance with correct direction so as to optimize information resources and improve enthusiasm of teachers, students and management staffs. The author analyzes main factors influencing the information construction and proposes corresponding measures, hoping to provide referential significance for colleges and universities.
\end{abstract}

\section{Introduction}

With the rapid development of information technology, informatization reform in all walks of life are keeping up with the times, to promote the university management information construction is the demand of social development, but also the way to survive in the fierce competition, the only way to make the education modernization, cultivate talents for social development. Colleges and universities through the reform of teaching mode, means, content and ideas to improve the level of teaching, scientific research and management services. In recent years, the informatization construction of university has made progress, the use of multimedia has simple towards multimedia, remote teaching, network information technology diversification combined with the direction of development, the college students in the use of "one card" is equivalent to personal identification in the school, for students to use, school management, and cloud computing things are gradually into the university. But in the information construction, many problems are exposed, the overall information construction environment is backward, there is no uniform construction standards, etc.

\section{Factors Influencing the Management and Information Construction at Colleges and Universities}

Firstly, colleges have weak awareness of information. The process of informatization construction in colleges and universities is also college educational ideas. Many managers and teachers of informatization construction lack of awareness of the traditional teaching management idea ingrained, and invested in the construction funds, but restricted by the construction personnel, affecting the process of informatization. Many teachers and students have little or no knowledge of the most advanced technologies like cloud computing and Internet of things.

Secondly, construction of information environment at colleges and universities lags behind. At present, one important factor hindering information construction at colleges and universities is environment construction. Information technology hardware and software equipment lags behind, so that the construction of network information is stagnant, due to funding constraints, the old equipment cannot be updated. There is only the hardware environment, even if the update of the equipment, but because of the old software, cannot fully use the hardware equipment, software and hardware equipment, the use of dislocation led to the waste of information resources.

Thirdly, there is no unified rules and regulations in the construction of University informatization. There is no uniform standard of informatization construction is restricting factors 
of college informatization construction, informatization construction in Colleges and universities is mainly to promote the informatization of education management of colleges and universities, but the University and college level, between various departments, each department because the software system is not uniform, according to the number of different types, resulting in a lot of management for information cannot be shared, forming an island effect of various departments and departments to establish information system according to their own needs, there is no complete planning, great limitations. There is no unified rules and regulations to make the information construction of colleges and universities lack of systematic, and become a stumbling block to the informatization of colleges and universities.

Fourthly, lack a perfect evaluation system. The level of information technology to measure the level of information assessment system, the use of evaluation system, the management of the university can grasp the specific situation of information construction in a timely manner, and accordingly put forward the corresponding solution. The evaluation system of the traditional information system is actually self-evaluation with a lack of objectivity. A lot of problems stand on our own point of view it is difficult to find knowledge, to the end of the year report and evaluation of colleges and universities, the evaluation content is too formal, not truly reflect the effectiveness of information technology.

Fifthly, teaching staffs have weak cultivation of information. With the development of information construction in Colleges and universities, the information literacy of teachers, administrators and managers has been gradually falling behind. Many colleges and universities administrative personnel of the information collection and evaluation ability is weak, so that the lack of information system, a chaos, information resources are not fully utilized. In the classroom teaching management, teachers' low utilization of information technology teaching means, ability to deal with information technology is weak, but not conducive to improve the teaching effect, a lot of network information mining, lack of capacity, which is not conducive to the information construction of colleges and universities of science. Due to the higher value of scientific research, the lack of attention to information technology personnel, there is no training to provide water, so that a lot of information literacy high staff turnover.

Sixthly, the integration of Information technology with various disciplines is low. The information is everywhere, combined with the various disciplines and information is still in the primary stage, many students do not pay attention to the non-computer professional computer course, in fact, computer basic education for all students, this is the basic hard information, can help students grasp the future work and life basic information means. The management is simple to basic computer courses as typing, learning software, but on information technology in-depth cognition, not to recognize the important role of programming and database, misleading the direction of information construction. In particular, the integration of other disciplines, it is fragmented, not in other disciplines throughout the course of information elements. Although in scientific research, there are a lot of information technology and the combination of research, but also need to use the actual teaching time, to find the appropriate point of entry.

\section{Measures of Information Construction at Colleges and Universities}

Firstly, improving the consciousness of management informatization construction in colleges and universities. University information construction is a part of the national informatization, in the state and the education sector, the strong support of the university should seize the opportunity to practice information technology demonstration projects and key projects. The leader plays an important role in the field of information revolution, should continue to improve awareness and information construction idea will do the planning, information construction as an important part of the overall development of the University, the appropriate input of construction funds, to encourage the professional practice of information engineering research. In addition, the management of colleges and universities should also help teachers and students to improve the concept of information, from the overall aspect of the development of the university to solve the problem with information technology. 
Secondly, creating scientific environment for the construction of University informatization. University informatization construction cannot be separated from the support of sufficient funds and scientific resource allocation. This requires the National Education Department of special funds to support the information construction of colleges and universities into a part of the national plan, in addition, universities can get social support and business cooperation opportunities, through investment, funding sources. The software and hardware environment construction should be the same attention as the basis for the construction of the informatization environment, the development of hardware cannot blindly become novel, matched to equipment and software. Colleges and universities can be carried out for the enterprise to engage in cooperation projects, to save money to buy hardware equipment, but also to support the production and development of experts and professors on the software. Finally, the information construction cannot be separated from the network artery, a stable network environment for college teaching, management and office to provide information security, therefore, colleges and universities should be based on the requirements of the times to upgrade the network.

Thirdly, improve the construction of information talents in Colleges and universities. Informatization construction of colleges and universities cannot be separated from the professional quality of information professionals, in order to improve the quality of teaching and scientific research, the use of scientific means to improve information management service system. First, colleges and universities should adhere to the people-oriented, pay attention to the construction of information technology personnel, the use of a variety of ways to help staff and workers in Colleges and universities to master the knowledge and ability of information. Secondly, the university leadership can establish an incentive mechanism to mobilize information by rewarding innovative talents, stimulate the potential to provide satisfactory salary and promotion opportunities, you can also launch the information talent into the research work of the University, to help teachers develop teaching information, open information process of the whole university. Finally, the management of colleges and universities should continue to improve their level of information technology, the most advanced information technology, mining and utilization of information resources for the decision-making and management of colleges and universities to provide information technology base. In addition, colleges and universities for the majority of staff and management of regular training, improve information service awareness, through the construction of information service platform to help teachers and administrators to master the ability to operate information technology. The teaching staff and management staff should improve the network operation ability, improve the service level, and make contribution to the information construction of colleges and universities through self-teaching.

Fourthly, establish unified information standards and improve the corresponding system construction. The information construction started in universities, a large number of information resources, complex information system, in order to carry out scientific classification, integration of various resources, realize the sharing of information resources of various departments and departments, the system is an urgent need to establish a unified encoding standard. The Ministry of education should also help colleges and universities to standardize the information. The establishment of a unified information standards can help universities to collect information, exchange information, processing information to provide convenient. The university can establish information construction overall goal according to the actual situation, formulate the overall goal and step by step, improve the information system construction, establish the information efficient operation mechanism, to provide institutional guarantee for the overall planning. All colleges and departments should cooperate with each other to establish and implement a unified standard and perfect information system.

Fifthly, establish a sound information evaluation system. Only the establishment of a scientific and accurate evaluation system, in order to effectively quantify the university informatization level and scientific research ability, timely feedback information construction in Colleges and universities problems, formulate measures to provide quantitative data support for the information construction of state and the Department of Education. The evaluation of informatization evaluation is the 
scientific research, logistics management, teaching and other aspects of the information, to assess whether appropriate, have an important impact on the decision-making, which is decided by the evaluation criteria, according to their own situation, the teaching situation of the information environment and the scientific research module to carry out assessment, universities can be timely. Develop and change information reform strategy.

Sixthly, improve the security of information system. The information related to scientific research resources, students' personal information, enhance security capabilities of information system can promote the steady progress of informatization construction in Colleges and universities. To prevent the information from being damaged and to improve the confidentiality of the information resources. You can install a firewall on the information system computer, isolate the internal and external, private and public networks, monitor the operation of the network in a timely manner, to avoid the leakage of information. In addition, information personnel in the operation of the computer, in order to improve the standard, install antivirus software regularly killing, important information to back up to prevent the adverse situation, check before installing new software or cyber source, and determine the safety.

\section{Conclusions}

Information construction at colleges and universities is a long-term process that needs to combine the specific situation of colleges and universities and their development stages, gradually increasing the investment of vigor and money, enhancing the awareness of information construction to cultivate and absorb more information talent and establish unified information standard so as to make full preparation for information construction at colleges and universities.

\section{References}

[1] Liu Yangyang. Analysis of Information Construction at Colleges and Universities and Study of Promotion Strategy [D]. Southwestern University of Finance and Economics, 2013.

[2] Cai Wenbo. Investigation and Analysis of Information Management Construction at Colleges and Universities [J]. Journal of Corps Education Institute, 2008(03):1-5.

[3] Cai Dehong. Research into Effective Strategies of Information Management Construction at Colleges and Universities [J]. Journal of Anshan Normal University, 2014(03):103-105.

[4] Song Jian, etc. Enlightenment of Information Development Stage on Information in Chinese Colleges and Universities [J]. China Educational Information, 2007(3): 8-10.

[5] Zheng Yabing. On Several Main Problems to be Solved in Information Construction at Colleges and Universities and Measures [J]. Education Information, 2005(12): 19-20.

[6] Zhao Guodong. Colleges in the Information Era: Information Development of Higher Education in the United States and the Reflections. Modern Educational Technologies, 2003,(5):11-6.

[7] Zhang Wenfeng. Review over Study into Information at China's Higher Education [J]. Liaoning Education Research, 2007,(8).

[8] Shen Peihua. Construction of Digital College Campus and Information Task. Educational Information, 2001,(11):7-11.

[9] Jiang Dongxing. Information Development at China's Colleges and Universities and Suggestions on Countermeasures. China's Information Circle. Issue 9 in 2011, 20-23.

[10]Nie Wenjun. On the Construction and Development of Financial Information at Colleges and Universities in Digital Campus [J]. Value Project, 2014, 35.

[11] Mu Xincan. Discussion of File Management in Colleges and Universities in Information 
Prospect [J]. Office Business, 2014, 19.

[12] Yu Xinxin. Current Status of File Information Management and Countermeasure Study [J] Office Business, 2014,19. 